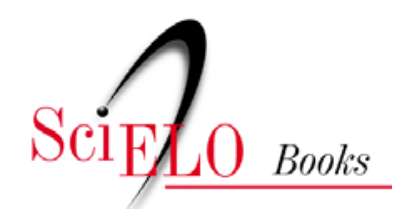

\title{
Capítulo 14 - Os encontros de Salas Abertas e seus desdobramentos
}

\author{
Majuí Menezes de Souza \\ Carolina Rizzotto Schirmer
}

\section{SciELO Books / SciELO Livros / SciELO Libros}

SOUZA, M. M., and SCHIRMER, C. R. Os encontros de Salas Abertas e seus desdobramentos. In: NUNES, L. R. O. P., and SCHIRMER, C. R., orgs. Salas abertas: formação de professores e práticas pedagógicas em comunicação alternativa e ampliada nas salas de recurso multifuncionais [online]. Rio de Janeiro: EDUERJ, 2017, pp. 293-298. ISBN: 978-85-7511-452-0. Available from: doi: 10.7476/9788575114520.016. Also available in ePUB from: http://books.scielo.org/id/xns62/epub/nunes-9788575114520.epub.

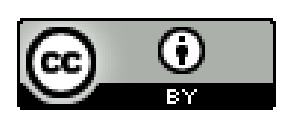

All the contents of this work, except where otherwise noted, is licensed under a Creative Commons Attribution 4.0 International license.

Todo o conteúdo deste trabalho, exceto quando houver ressalva, é publicado sob a licença Creative Commons Atribição 4.0.

Todo el contenido de esta obra, excepto donde se indique lo contrario, está bajo licencia de la licencia Creative Commons $\underline{\text { Reconocimento 4.0. }}$ 


\section{Capítulo 14 - Os encontros de Salas Abertas e seus desdobramentos}

Majui Menezes de Souza ${ }^{1}$ Carolina Rizzotto Schirmer ${ }^{2}$

Entre todas as atividades realizadas no curso "Salas de Recursos Multifuncionais de Referência”, os encontros de Salas Abertas mostraram ser particularmente importantes, pois possibilitaram, mediante uma extensa troca de informações entre os professores, a ampliação das ações inclusivas dentro das escolas e da interação entre os profissionais de AEE (Atendimento Educacional Especializado).

Já em minha primeira experiência, no dia 13 de julho de 2016, o encontro ficou marcado por diversos pontos positivos. Houve bastantes trocas de informações, debates, dinâmicas de grupo e, principalmente, muitas trocas de experiências entre os trinta participantes (divididos em dois turnos).

A primeira atividade foi a apresentação do vídeo Processos de Comunica$c_{c} a o^{3}$, produzido para o curso de Especialização em Coordenação Pedagógica da UFSC, na Sala Práticas e Espaços de Comunicação, pela professora D. K.

1 Secretaria Municipal de Educação do Rio de Janeiro. E-mail: majuisouza@yahoo.com.br.

2 Professora adjunta da Faculdade de Educação da UERJ. E-mail: ead.carolina@gmail. com.

3 Processos de Comunicação. Disponível em: https://www.youtube.com/watch?v=_ C3AmzKpJbQ\&t=100s. 
R., com o apoio do Laboratório de Novas Tecnologias (Lantec)/Centro de Ciências da Educação (CED), e disponibilizado publicamente por meio da internet. Trata-se de um stop-motion que explica o modelo de comunicação de Shannon-Weaver. O modelo descreve, entre outras coisas, o ruído, "termo que se refere a possíveis interferências que podem diferenciar a mensagem enviada da mensagem recebida”. Esse ponto foi amplamente discutido após a apresentação do vídeo. Observou-se, de forma muito pertinente, que até mesmo indivíduos sem prejuízo na comunicação estão sujeitos a essas falhas.

Após a exibição do vídeo, demos início à dinâmica de grupo, atividade essencial para desenvolver o tema abordado. A ideia central era de demonstrar, na prática, a codificação e a decodificação da mensagem a ser veiculada, a influência do ruído e como a utilização de uma ferramenta pode suprimir falhas e facilitar a comunicação, quando o ruído é particularmente expressivo, como, por exemplo, no caso de pessoas com prejuízo na comunicação.

A dinâmica de grupo foi feita da seguinte forma: dividiu-se o grupo em duplas em que um seria o emissor e o outro o receptor. $\mathrm{O}$ emissor recebeu uma mensagem simples, desconhecida pelo receptor, e deveria, utilizando-se apenas de movimentos muito limitados, comunicar a mensagem ao receptor sem fazer gestos óbvios. Dessa forma, simula-se uma situação na qual o emissor tem um prejuízo enorme na comunicação, como no caso de um indivíduo com paralisia cerebral. Como resultado, os receptores entenderam erroneamente ou não compreenderam de forma alguma as mensagens recebidas.

Após essa atividade, foram apresentados os slides sobre a CAA - Comunicação Alternativa Ampliada -, nos quais foi demonstrada a enorme diversidade de pranchas que podem ser usadas em cada caso, e alguns vídeos de atendimentos feitos pela Oficina Vivencial, mostrando a importância da comunicação para o aluno, suas inúmeras formas de se comunicar e as várias maneiras de ampliar essa comunicação. Em um desses vídeos, uma aluna com deficiência intelectual e prejuízo na oralidade participava do jogo conhecido como Cara a cara, no qual os participantes reúnem informações dadas pelo adversário para descobrir qual é o personagem, por meio de uma filtragem, com base nas características físicas dele. A aluna em questão, inicialmente não conseguiu comunicar as informaçóes pretendidas para o decorrer do jogo, escolhendo um personagem que era da sua preferência e não aquele oculto pelo adversário. Entretanto, ao reiniciar a atividade utilizando a prancha de CAA, ela foi perfeitamente capaz de comunicar as informações necessárias, 
e o jogo transcorreu de acordo com as regras. A prancha utilizada continha figuras com diversas características físicas, como cor dos olhos, cabelos, sexo do personagem, roupas etc. A aluna, então, pôde apontar para as figuras que representavam a característica a ser comunicada e, com isso, foi capaz de transmitir a mensagem pretendida. Ao final da exibição dos slides e de todo o debate, as duplas da dinâmica de grupo feita na abertura do encontro foram reunidas novamente, porém, utilizando pranchas de CAA para transmitirem um ao outro a mensagem combinada no início da atividade; dessa vez, obtendo melhores resultados.

Durante a primeira parte da dinâmica, os emissores de cada dupla relataram que, durante a tentativa de comunicação sem a prancha de CAA, sentiram-se ansiosos e angustiados ao tentarem transmitir a mensagem ao receptor que era incapaz de compreendê-la. Ao fazê-lo utilizando as pranchas, os resultados foram satisfatórios. Todos os receptores conseguiram compreender o que era transmitido pelos emissores, demonstrando a importância de tais ferramentas na comunicação. Os emissores, por sua vez, relataram que a prancha facilitou muito a comunicação, de modo que, mesmo com movimentos limitados, a informação era facilmente transmitida ao receptor, e o feedback era positivo.

Durante as pausas na apresentação dos vídeos e dos slides, houve muita troca de informações entre os professores presentes. Estes tiveram a oportunidade de relatar experiências, elucidar dúvidas, fazer suas colocaçóes, complementações e sugestões. Experiências positivas com calendário de antecipação foram relatadas, bem como outros tipos de prancha. Uma dúvida muito pertinente surgida durante o debate foi sobre a utilização de fotos ou gravuras e desenhos nas pranchas: concluiu-se que o uso da CAA pode ser iniciado com fotos, passando para figuras maiores e, depois, reduzidas, ou, dependendo do grau de autonomia do aluno, pode-se pular essa transição e utilizar diretamente os símbolos, universalizando o uso da prancha.

O resultado do segundo encontro, realizado no dia 9 de novembro de 2016 e integrado por 22 participantes, também divididos em dois turnos, foi igualmente enriquecedor. Debatemos e problematizamos o fato de que existe um hábito de se associar a CAA apenas a Transtornos do Espectro Autista, deixando de contemplar as muitas outras causas para o prejuízo da comunicação, como a paralisia cerebral. 
Foi apresentado o vídeo Por que Heloisa? ${ }^{4}$, produzido pela Secretaria dos Direitos da Pessoa com Deficiência do Estado de São Paulo e disponibilizado na internet. Ele conta a história de uma menina com paralisia cerebral durante seus primeiros contatos com uma nova escola. A animação aborda, entre outros temas, a acessibilidade e a inclusão, mas não fala sobre a CAA, apesar de o prejuízo da comunicação de Heloísa ser claramente demonstrado em diversas situações. Foi nesse ponto que surgiu a oportunidade de levantar essa questão de forma objetiva pelo grupo.

Algumas das situaçóes vividas pela personagem, em que a comunicação era difícil, foram prontamente identificadas pelo grupo, que também apontou a prática das pranchas de CAA como solução. A única referência à comunicação alternativa foi a utilização de um acionador por meio do qual Heloísa comunicou que desejava um lápis da cor amarela. Porém, nos diversos ambientes em que Heloísa precisava interagir, não havia nenhum calendário ou dispositivo móvel com aplicativo de CAA que pudesse facilitar sua comunicação.

Foi falado também sobre acessibilidade e inclusão, temas centrais no filme, bem como a importância do estímulo para que a pessoa com deficiência tenha sempre mais autonomia na realização de suas tarefas. Dúvidas que também surgiram no debate, como algumas dificuldades em se elaborar uma prancha, foram discutidas.

Finalizando o debate, houve a apresentação de slides, na qual foi demonstrada a importância da utilização da CAA para qualquer aluno com prejuízo na comunicação. Foi abordada também a atuação do professor de Sala de Recursos nesse processo.

Falamos sobre o programa de computador para elaboração de pranchas de CAA chamado Boardmaker, um recurso caro e de utilização restrita a uma única licença de usuário. Isso faz com que, para muitas escolas, esse recurso torne-se inacessível, embora seja extremamente eficaz. Além disso, é um programa pouco intuitivo, havendo complexidade na utilização de suas funções. Uma alternativa ao Boardmaker demonstrada foi o portal ARASAAC, uma ferramenta online e gratuita para a elaboração de pranchas. Foi então que se levantou o problema da falta de sinal de internet em muitas das escolas da

4 Por que Heloisa?. Disponível em: https://www.youtube.com/watch?v=f5vNAwmgZU4. 
rede municipal, o que impossibilita até mesmo a utilização dessa ferramenta inteiramente gratuita.

Em seguida, foi apresentado um organograma com palavras, expressões e situaçôes relacionadas ao PEI - Planejamento Educacional Individualizado -, que devem ser levadas em consideração para a elaboração desse documento. Concluiu-se que o PEI visa a promover um conhecimento aprofundado do histórico do aluno, suas características, habilidades e necessidades, garantindo, assim, um currículo adaptado que deve ser elaborado em conjunto com toda a equipe pedagógica que atende o aluno incluído, para que este possa ser avaliado de forma coerente.

Finalmente, realizamos uma oficina de pranchas de CAA, com imagens relacionadas ao ambiente escolar, na qual os professores puderam elaborar suas pranchas. Estas foram plastificadas, e cada professor pôde levar consigo seu material para a utilização em sala de aula, quando necessário.

Durante a apresentação dos slides, os professores apontaram dificuldades que surgem ao se elaborar uma prancha de CAA e aproveitaram para tirar dúvidas sobre isso e sobre a utilização do Portal ARASAAC. Também foi demonstrado o tutorial do portal e, então, puderam conhecer melhor a plataforma.

\section{Conclusão}

Os eventos das Salas Abertas possibilitaram uma troca enorme de informações entre os participantes. Métodos, dúvidas, experiências, sugestôes e dificuldades foram discutidos amplamente, bem como as políticas públicas para a educação especial. Ficou bastante claro, durante o evento, que, na maioria das vezes, a inclusão ainda é vista como um problema, e não como uma solução. O tema nem sempre é ponto pacífico e, frequentemente, o professor da Sala de Recursos se sente solitário em seu trabalho dentro da escola. E, por meio de um trabalho de conscientização, essa situação está se desconstruindo. Ações como o dia da conscientização do autismo, dia da conscientização da Síndrome de Down, capacitações oferecidas pelo IHA Instituto Helena Antipoff (que também abrangem coordenadores e professo- 
res de sala comum com alunos incluídos etc.) -, entre outras, visam a mitigar esse problema e criar uma cultura inclusiva na rede educacional.

A convergência e consequente troca de experiências entre tantos profissionais da educação especial mostrou-se como sendo o ponto mais importante do encontro. São pessoas que estão separadas fisicamente nos seus trabalhos e que, devido à diversidade e amplitude do tema, aumentam exponencialmente sua capacidade de atuação com esse tipo de interação. Cada aluno tem suas peculiaridades, e cada caso é um desafio. É durante encontros como esse que horizontes se ampliam, novas possibilidades surgem, e o maior beneficiado é o aluno. 